\title{
Improvement of the elements of technology of growing rod- shaped millet in the conditions Forest Steppe of Ukraine
}

\author{
Humentyk M. \\ Institute of Bioenergy Crops and Sugar Beets of NAAS \\ 25 Klinichna Str., Kyiv, 03141, Ukraine \\ e-mail: hmy@ukr.net \\ ORCID: 0000-0001-9052- 9650
}

Goal. To improve the elements of technology, methods of soil preparation and sowing of seeds, to increase the productivity of growing biomass of rod-shaped millet for the production of solid biofuels in the Western Forest-Steppe, taking into account the biological characteristics of plant development. Methods. Field, laboratory, measuring, comparative, statistical, and dispersion. Results. The results of research on improving the elements of technology for growing biomass of rod-shaped millet in the Western ForestSteppe of Ukraine - pre-sowing soil preparation and sowing of millet seeds together with seeds of the beacon culture, which allowed early tillage and significantly reduce weeds. The highest biomass productivity of rod-shaped millet and energy yield (377.7 GJ/ha) was at a row spacing of $30 \mathrm{~cm}$. Conclusions. Rodshaped millet in the first year of the growing season is sensitive to soil moisture and temperature, which significantly influences the friendliness of the germination of seedlings. Favorable conditions for growing biomass of rod-shaped millet in the Western Forest-Steppe zone can be significantly improved by using 3time pre-sowing tillage with harrows and sowing seeds with an optimal row spacing of $30 \mathrm{~cm}$ together with seeds of beacon white mustard.

Key words: sowing, pre-sowing and inter-row tillage, row spacing, biomass, solid biofuels. DOI: https://doi.org/10.31073/agrovisnyk202009-02

In the world, more and more attention is being paid to the use of renewable energy resources. Most countries give priority to the use of feedstock grown from bioenergy crops. Under these conditions, certain changes will take place in the agricultural market and there is a need to develop and implement scientifically sound technologies for growing biomass of highly productive bioenergy crops [1, 2]. According to research data $[3,4]$, in recent years, Ukraine has also seen a significant increase in the number of new renewable energy facilities that use biomass for the production of solid biofuels. [5-8].

Switchgrass (Panicum virgatum L.) is one crop from a wide range of high-yielding perennials for biofuel production. Switchgrass biomass contains a significant amount of cellulose and lignin and is considered the most suitable feedstock for biofuel production [9]. Increased demand for biomass along with the expansion of commercial areas under perennial grasses, including switchgrass, for the production of biofuels in Ukraine, necessitates a need to develop effective technologies for its cultivation [10-12]. Particularly, there is a need for scientifically sound methods of seedbed preparation, sowing, tending crops, and studying the quantitative impact of these factors on the formation of crop productivity. To achieve the goal in the research process, the following tasks were solved: to develop and substantiate the most effective method of seedbed preparation for switchgrass; to determine and substantiate the rational planting design for switchgrass; to find out the optimal row spacing $[13,14]$.

The purpose of research - to improve the elements of technology, methods of soil preparation and sowing seeds, increase productivity cultivation of biomass of millet rod in the conditions of the Western Forest-Steppe taking into account biological features of development of plants. To achieve it, it is necessary to develop and substantiate the most effective way of pre-sowing tillage for sowing of millet, to determine a rational scheme of sowing its seeds, to establish the optimal width between rows.

Research methods. The research to improve the components of switchgrass growing technology was carried in the years 2013-2016 at the Yaltushkiv Research Breeding Station (Bar district, Vinnytsia region), located in the western part of Ukrainian Forest-Steppe. The soil for the experiment was grey forest podzolic medium-loam weakly acidic type with the following agrochemical characteristics: humus content of $1.5 \%$, a $\mathrm{pH}_{\text {sal }}$ of 5.5 , hydrolytic acidity of 2.5-2.9 mg/equivalent per $100 \mathrm{~g}$ of soil, degree of alkali saturation of $80-83 \%$, alkaline hydrolyzed nitrogen content (according to Cornfield) of $75.0-77.6 \mathrm{mg} / \mathrm{kg}$, mobile phosphorus content $\left(\mathrm{P}_{2} \mathrm{O}_{5}\right)$ of $127.3-131.0 \mathrm{mg} / \mathrm{kg}$, and exchange potassium $\left(\mathrm{K}_{2} \mathrm{O}\right)$ (according to Kirsanov)of $115.0-123.4 \mathrm{mg} / \mathrm{kg}$ of soil. Design of the experiment involved the study of switchgrass productivity as affected by the following methods of seedbed preparation: 1 - double cultivation to a depth of 3-4 cm using cultivator USMK-5,4; 2 - three-time cultivation; 3 - double cultivation using harrow to a depth of 2-3 cm; $4-$ three-time cultivation using harrow to a depth of $2-3 \mathrm{~cm} ; 5-$ direct sowing without seedbed preparation (1row spacing of $15 \mathrm{~cm}$, with white mustard as a marker crop; 2 - row spacing of $30 \mathrm{~cm}$, with white mustard as a marker crop, 3 - row spacing of $45 \mathrm{~cm}$, with white mustard as a marker crop; 4 - row spacing of $15 \mathrm{~cm}$, without marker crop. The total plot area was $100 \mathrm{~m}^{2}$, accounting area $50 \mathrm{~m}^{2}$. The experiment was conducted with three replications.

The research was conducted in accordance with the methods of field experiments [15]. Harvesting of switchgrass biomass and yield accounting was carried out in late October and early November. 
Research results. The study has shown that the intensity of switchgrass seeds germination and seedling vigour are determined by such indicators as soil temperature and humidity. Under low temperature and soil moisture content, plant germination retards. A long period of lacking heat and moisture can lead to plant death. However, the decisive factor in seed germination and rapid germination is soil moisture, which decreases rapidly in spring, especially during the spring drought. Soil moisture reserves formed in early spring during snowmelt do not always provide the necessary conditions for plant growth and development.

Weather conditions over the years of research varied. The amount of precipitation most favourable for the growth and development of switchgrass plants was in 2013, 2014, and 2015, when it exceeded the long-term average in May and June. The aridest and unfavourable year was 2016 when in May and June precipitation was less than the average at the time of sprouting (Fig. 1).

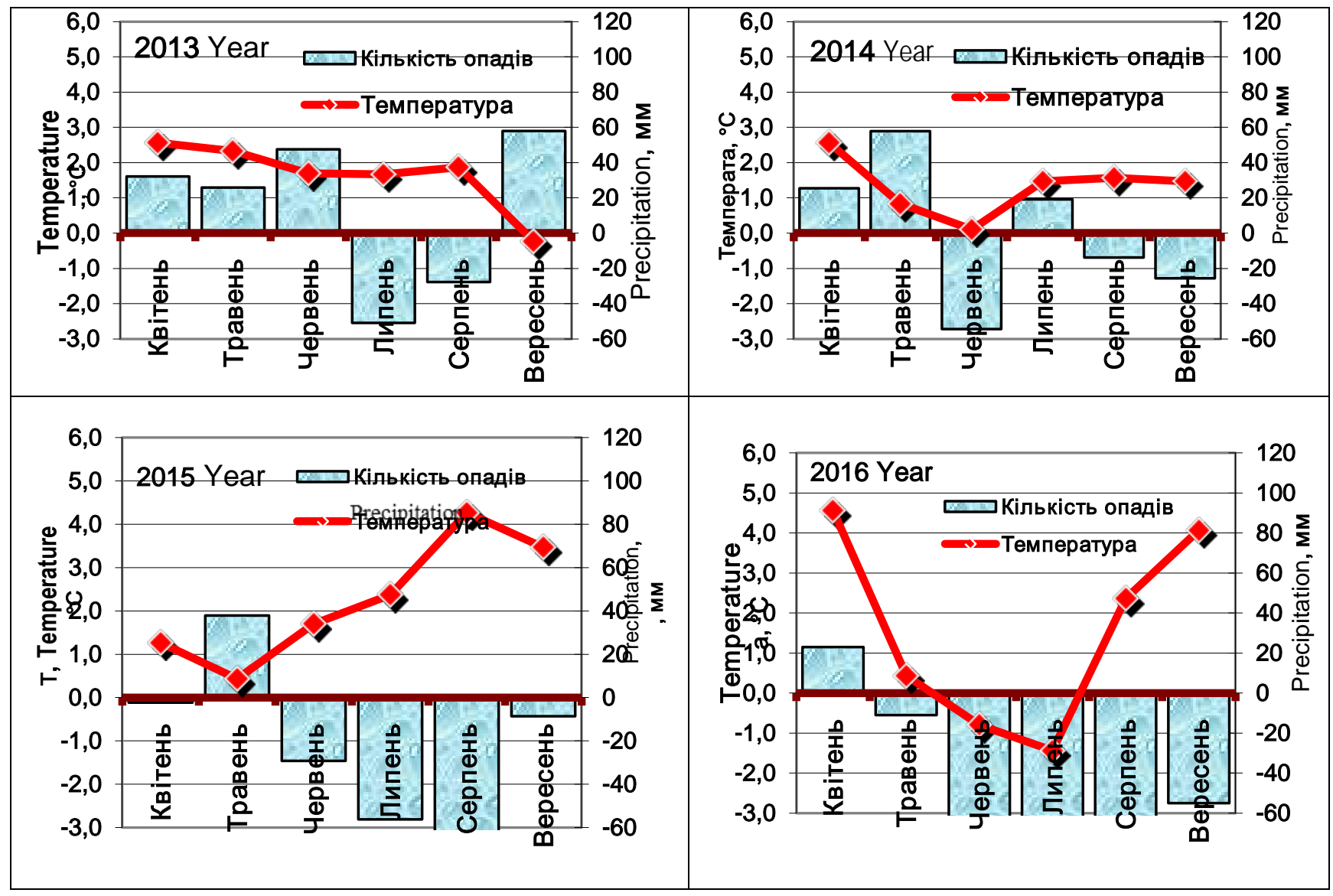

Fig. 1. Deviation of air temperature and precipitation from the average long-term values (Yaltushkiv RBS, 2013-2016)

Analysis of soil moisture at the time of sowing switchgrass during the years of experiment has shown that its content in the arable soil layer is constantly changing and depends on weather conditions. It was found that the field germination of switchgrass may be affected not only by the timing of sowing but also by seedling vigour and effective mechanized tending crops.

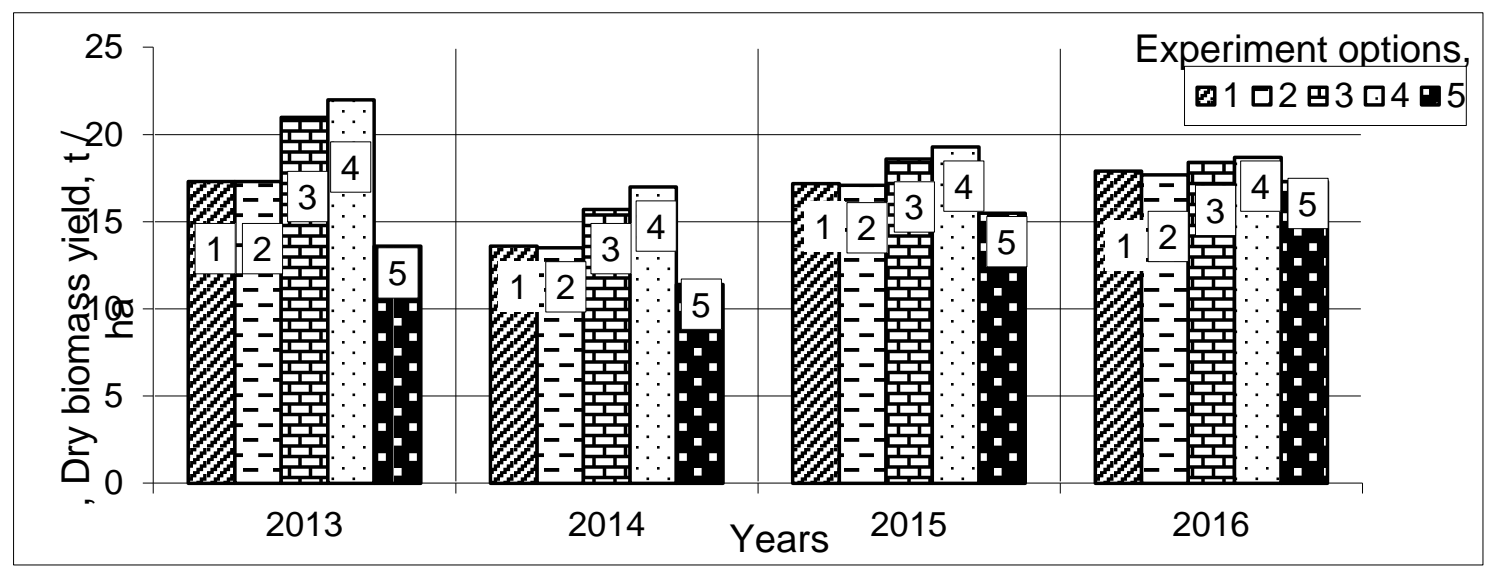

Fig. 2. The productivity of switchgrass dry biomass as affected by seedbed prepardion method (2013-2016): 1- double cultivation to a depth of 3-4 cm with cultivator USMK-5,4; 2 - three-time cultivation; 
3 - double tillage with a harrow to a depth of $2-3 \mathrm{~cm}$.; 4 - three-time tillage with a harrow to a depth of 2-3 $\mathrm{cm} ; 5$ - direct sowing without seedbed preparation.

1. Energy characteristics of the experiment treatments (2013-2013)

\begin{tabular}{|c|l|c|c|c|c|c|}
\hline No. & $\begin{array}{l}\text { Method of seedbed } \\
\text { preparation }\end{array}$ & $\begin{array}{c}\text { Yield of } \\
\text { dry } \\
\text { biomass } \\
\text { (t/ha) }\end{array}$ & $\begin{array}{c}\text { Calorific } \\
\text { value of } \\
\text { biofuel } \\
(\mathrm{MJ} / \mathrm{kg})\end{array}$ & $\begin{array}{c}\text { Biofuel output } \\
\text { (kg/ha) }\end{array}$ & $\begin{array}{c}\text { Yield of } \\
\text { conventional } \\
\text { fuel } \\
(\mathrm{kg} / \mathrm{ha}, \mathrm{l} / \mathrm{ha})\end{array}$ & $\begin{array}{c}\text { Energy } \\
\text { yield } \\
\text { (GJ/ha) }\end{array}$ \\
\hline 1 & $\begin{array}{l}\text { Double cultivation to } \\
\text { a depth of 3-4 cm } \\
\text { USMK-5.4 }\end{array}$ & 16.4 & 17.0 & 18040 & 10824 & 278.80 \\
\hline 2 & $\begin{array}{l}\text { Three-time } \\
\text { cultivation to a depth } \\
\text { of 3-4 cm USMK-5.4 }\end{array}$ & 16.3 & 17.0 & 17930 & 10758 & 277.10 \\
\hline 3 & $\begin{array}{l}\text { Double tillage with } \\
\text { harrows to a depth of } \\
\text { 2-3 cm }\end{array}$ & 18.4 & 17.0 & 20240 & 12144 & 312.80 \\
\hline 4 & $\begin{array}{l}\text { Triple harrowing to a } \\
\text { depth of 2-3 cm }\end{array}$ & 19.2 & 17.0 & 21120 & 12672 & 326.40 \\
\hline 5 & $\begin{array}{l}\text { Direct sowing without } \\
\text { seedbed preparation }\end{array}$ & 14.4 & 17.0 & 15840 & 9504 & 244.80 \\
\hline
\end{tabular}

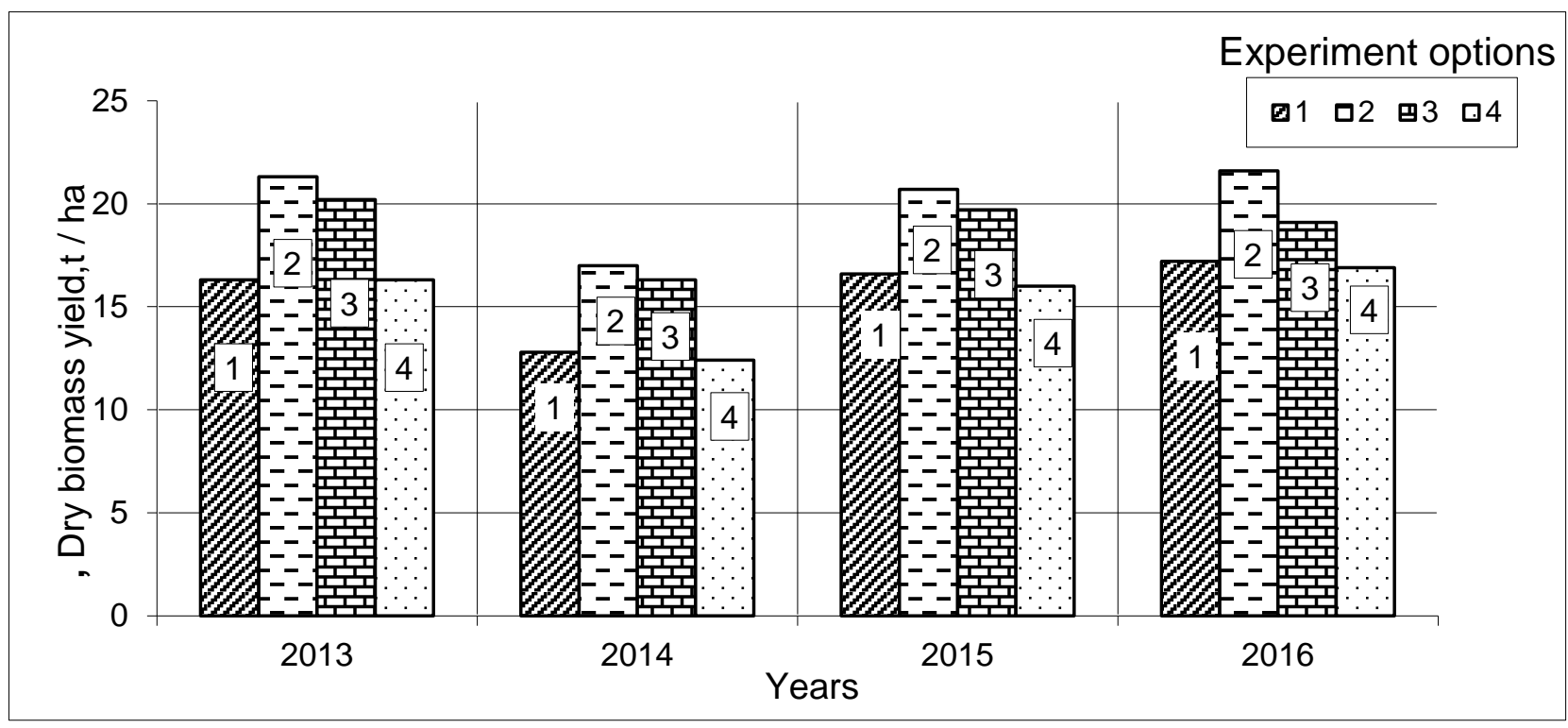

Fig. 3. Switchgrass productivity as affected by methods of sowing (2013-2016):

1- width between rows $15 \mathrm{~cm}$, with marker crop; 2 - row spacing of $30 \mathrm{~cm}$, with marker crop, 3 - width row spacing $45 \mathrm{~cm}$, with marker crop; 4 - row spacing $15 \mathrm{~cm}$, without marker crop.

\section{Energy characteristics of growing switchgrass biomass under different methods of sowing} (2013-2016)

\begin{tabular}{|c|l|c|c|c|c|c|}
\hline No. & Method of sowing & $\begin{array}{c}\text { Yield of dry } \\
\text { biomass } \\
\text { (t/ha) }\end{array}$ & $\begin{array}{c}\text { Calorific value of } \\
\text { biofuel (MJ/kg) }\end{array}$ & $\begin{array}{c}\text { Biofuel } \\
\text { output } \\
\text { (kg/ha) }\end{array}$ & $\begin{array}{c}\text { Yield of } \\
\text { conventional } \\
\text { fuel } \\
\text { (kg/ha, l/ha) }\end{array}$ & $\begin{array}{c}\text { Energy yield } \\
\text { (GJ/ha) }\end{array}$ \\
\hline 1 & $\begin{array}{l}\text { Row spacing of 15 } \\
\text { cm, with marker } \\
\text { crop }\end{array}$ & 15.8 & 17.0 & 17380 & 10428 & 295.46 \\
\hline 2 & $\begin{array}{l}\text { Row spacing of } 30 \\
\text { cm, with marker } \\
\text { crop }\end{array}$ & 20.2 & 17.0 & 22220 & 13332 & 377.74 \\
\hline 3 & $\begin{array}{l}\text { Row spacing of 45 } \\
\text { cm with marker } \\
\text { crop }\end{array}$ & 18.8 & 17.0 & 20680 & 12408 & 351.56 \\
\hline 4 & $\begin{array}{l}\text { Row spacing of 15 } \\
\text { cm, without marker } \\
\text { crop }\end{array}$ & 15.4 & 17.0 & 16940 & 10164 & 287.98 \\
\hline
\end{tabular}


Over the years of research, it was found that the weakest link in the technology of growing swithchgrass is severe weed infestation of sowings during the period of plant germination in the first year of vegetation. The most effective way of seedbed preparation is three-time tillage to a depth of $2-3 \mathrm{~cm}$. In this case, the highest value of energy yield was obtained (326.40 GJ/ha).

The use of the method of switchgrass seed sowing along with the seeds of marker crop (white mustard) made it possible to carry out earlier inter-row tillage and significantly reduced weed infestation of crops. Solving this problem in the first year of growing removed the problem of weed infestation in the forthcoming years (Fig. 2, Table 1)

The use of the presented technology of seedbed preparation and sowing switchgrass with a row spacing of $30 \mathrm{~cm}$ along with marker crop (white mustard) ensure the necessary conditions for tending crops during vegetation, increase crop productivity and provide the highest energy yield of 377.7 GJ/ha (Fig. 3, Table 2).

\section{Conclusions}

An agronomical specific of switchgrass in the first year of growing is its increased sensitivity to soil moisture and temperature at the beginning of growth and development which determine the seedling vigour and play an important role in further mechanized tending crops.

Favourable conditions for switchgrass germination with taking into account agronomical and biological features in the western part of Ukrainian Forest-Steppe can be ensured by three-time harrowing and sowing switchgrass along with marker crop (white mustard) at the optimal row spacing of $30 \mathrm{~cm}$.

\section{References}

1. Bondar, V. S., \& Fursa, A. V. (2015). Ekonomichne obgruntuvannia tekhnolohii vyroshchuvannia i pererobky roslynnoi biosyrovyny na tverdi vydy palyva. [Economic substantiation of technologies of cultivation and processing biomass into solid fuels]. Economics of agro-industrial complex, 3, 22-27. [in Ukrainian].

2. Bondar, V. S., Fursa, A. V., \& Humentyk, M. Ya. (2018). Stratehiia ta priorytety rozvytku bioenerhetyky v Ukraini [Strategy and priorities of bioenergy development in Ukraine]. Economics of agro-industrial complex, 3, 17-25. [in Ukrainian].

3. Oharenko, Yu. (Ed.), \& Aliieva, O. (Ed.) (2017). Perekhid Ukrainy na vidnovliuvalnu enerhetyku do 2050 roku: zvit za rezultatamy modeliuvannia bazovoho ta alternatyvnykh stsenariiv rozvytku bioenerhetychnoho sektoru [Ukraine's transition to renewable energy by 2050: a report on the results of modeling the basic and alternative scenarios for the development of the bioenergy sector]. Kyiv: ART BOOK. [in Ukrainian]

4. Heletukha, H. H., Zhelizna, T. A., Kramar, V. H., \& Kucheruk, P. P. (2015). Perspektyvy rozvytku bioenerhetyky yak instrument zamishchennia pryrodnoho hazu v Ukraini. Bioenerhetychna asotsiatsiia Ukrainy. [Prospects for the development of bioenergy as a tool for replacing natural gas in Ukraine. Bioenergy Association of Ukraine]. [in Ukrainian]

5. Heletukha, H, Oliinyk, Ye., Antonechko, V., Chaplykhin, S., Hubenko, V., \& Radchenko, S. (2016). Provedennia kompleksnoho doslidzhennia rynkukotliv, shcho pratsiuiut na biomasi $v$ Ukraini [A comprehensive experiment of the market of boilers for biomass in Ukraine]. United Nations Development Programme. Kyiv. [in Ukrainian].

6. Heletukha, H., H., Zhelizna, T. A., Kucheruk, P. P., \& Oliinyk, E. M. (2018). Suchasnyi stan ta perspektyvy rozvytku bioenerhetyky $v$ Ukraini [Current state and prospects of bioenergy development in Ukraine]. [in Ukrainian].

7. Ihnatenko, O. P. (2016). Biomasa vykorystannia v munitsypalnomu sektori: praktychnyi posibnyk. Proekt PROON / HEF «Rozvytok ta komertsializatsiia bioenerhetychnykh tekhnolohii ta munitsypalnoho sektoru Ukrainy» [Biomass use in the municipal sector: a practical guide. PROON/HEF project "Development and commercialization of bioenergy technologies and the municipal sector of Ukraine"]. Kyiv. [in Ukrainian]

8. Vidnovliuvalna enerhetyka v Ukraini: sohodennia ta perspektyvy. Ukrainska asotsiatsiia vidnovliuvalnoi enerhetyky. Zvit. [Renewable energy in Ukraine: present and prospects. Ukrainian Renewable Energy Association] (2016). [in Ukrainian]

9. Comis, D. (2006). Switching to switchgrass makes sense, in Agricultural Research, July.

10. Petrychenko, S. M., Herasymenko, O. V., \& Honcharuk, H. S. (2011). Perspektyvy vyroshchuvannia svitchhrasu yak alternatyvnoho dzherela enerhii $v$ Ukraini [Prospects for growing switchgrass as an alternative energy source in Ukraine] Sugar beets, 4, 13-14. [in Ukrainian]

11. Cherney J. H., Cherney D.J.R., Paddock K.M. (2018) Biomass Yield and Composition of Switchgrass Bales on Marginal Land as Influenced by Harvest Management Scheme. Bioenerg. Res., 11(1), 34-43.

12. Burli P., E. Forgoston, Lal P. et al. (2017) Adoption of switchgrass cultivation for biofuel under uncertainty: A discrete-time modeling approach. Biomass and Bioenergy, 105, 110.

13. Kurylo, V. L., Humentyk, M. Ya., \& Kaskiv, V. V. (2013). Vplyv strokiv sivby ta hlybyny zahortannia nasinnia svitchhrasu prosa lozovydnoho na polovu skhozhist $v$ umovakh zakhidnoi chastyny Lisostepu Ukrainy [Influence of sowing dates and burying depth on the field germination of switchgrass in the conditions of the western part of the Forest-Steppe of Ukraine]. Scientific papers of the Institute of Bioenergy Crops and Sugar Beet, 17(2), 358-361. [in Ukrainian] 
14. Kulyk, M. I. (2013). Vplyv umov vyroshchuvannia na vrozhainist fitomasy svitchhrasu druhoho roku vehetatsii [Influence of growing conditions on switchgrass phytomass yield on the second year of vegetation]. Bulletin of Poltava State Academy, 2, 30-35. [in Ukrainian]

15. Dospekhov, B.A. (1985). Metodika polevogo dela [Methods of field experiment]. Moscow: Agropromizdat. [in Russian] 